\title{
AN ANALYSIS OF ENGLISH TEXTBOOK IN THE FIRST GRADE OF JUNIOR HIGH SCHOOL
}

\author{
Tyas Desita Wengrum \\ University of Mitra Indonesia \\ tyaswengrum@umitra.ac.id
}

\begin{abstract}
Received: 2 June 2020
Accepted: 14 July 2020

Published : 31 July 2020

Abstract

This research is attempted to analyze text reading from two different textbook publishers, Erlangga and Yudhistira Ghalia in the first grade of Junior High School. Those two textbooks are designed based on Curriculum 2013. The analysis is focused on the three aspects of Systemic Functional Linguistics; ideational meaning (transitivity), interpersonal meaning (mood structure), and textual meaning (themerheme). Those three aspects are used to analyze the contents of text reading in those two textbooks. In addition, clause complex, nominal group and lexis are used to find out the readability of those two textbooks that used by Junior High School students. These data analyzed by triangulation method. To analyze the data, the researcher used domain analysis, taxonomy analysis, componential analysis, and theme- culture analysis. The finding showed that content of reading text in Erlangga's book is more detail in describing an object than Yudhistira Ghalia's book. It can be concluded that Yudhistira Ghalia's Book is more difficult and complicated for students of Junior High School than Erlangga's book.
\end{abstract}

Keywords: text reading, textbook, systemic functional linguistics

To cite this article:

Wengrum, T. D. (2020). An Analysis of English Textbook in the First Grade of Junior High School. Jurnal of Reseacrh on Language

Education, 1(1), 26-30.

\section{INTRODUCTION}

The theory of Systemic Functional Linguistics (SFL) is selected as it approaches discourse analysis in this research. It is based on the thought that this approach is proven to be able to answer many language problems, either by micro and macro level. This opinion supported by direct revelation given by Eggins (2004: 2-3), SFL is considered quite reasonable and useful to study the text dealing with language education, child language development, computational linguistics, media discourse and casual conversation. Halliday (1994) recommend 21 grains relevant application of SFL. Besides, the strength of SFL there is on its holistic view to language that considers language as semiotic social.

According to Teich (1992) and Eggins (2004) language is a tool to establish and maintain social relationship. Each text has the difference characteristic of linguistic and social fact. It can be seen from the structure and texture which built the text. In this research that is explained about analysis of the text to prove, how to build a text that good and intact. The text used in the analysis is reading text from two book publishers (Erlangga and Yudhistira Ghalia), based on Curriculum 2013 that used by Junior High School students.

Previously, school students in Indonesia usually used students' workbook because it could give beneficial impact and as a source for students (Utami, et al., 2020). However, day by day, the advancement source for curriculum 2013 has improved, especially in a form of textbook (Qodriani and Kardiansyah, 2018). Thus, in this research, the researcher chooses reading text from two books publishers, Erlangga and Yudhistira Ghalia in the first grade of Junior High School to compare the book which is easier to understand for students. Those two text books are designed based on Curriculum 2013. Erlangga's book is well known by almost all students in Indonesia, also educators who involved in educational processes. Erlangga's book is known as the best quality in printing. Next publisher is Yudhistira Ghalia. This publisher is always maintaining the quality of books by designing the layout in maximal quality. So, the pages of books do not only contain the subject matter, but also with consideration due to esthetic aspects. The aim of this research are ideational meaning, interpersonal meaning, and textual meaning that realized in reading text from two book publishers (Erlangga and Yudhistira 
Ghalia) and readability in a reading text in English book from two books publishers (Erlangga and Yudhistira Ghalia.

Previous research on the analysis of textbooks was conducted by Nurdaeni (2013) entitled "Analysis of Elementary School English Textbooks Based on Writing Textbook Standards in the Third Grade of Layungsari State Elementary School". Furthermore, the research tends to discuss language skills and media use. Textbook research has also been carried out by Muqoffi (2013) entitled "Analysis of the Ta'lim Al-Lughah Al-'Arrabiyyah Arabic Language Education in the First Grade of Muhammadiyah Junior High School/ MTs". This study focuses on the theory of the preparation of textbooks, namely the selection, repetition, gradation, and presentation. Both studies have not yet discussed transitivity, themes, mood structure, complex clauses, nominal groups, and lexis.

Naz, Alvi, and Baseer (2012) in an article entitled "Political Language of Benazir Bhutto: A Transitivity Analysis of Her Speech 'Democrization in Pakistan", analyzing the linguistic form and function and language manipulation that Benazir Bhutto used by using transitivity. Furthermore, Ariana and Asi (2014) in their article entitled "An Analysis of Linguistic Competence in Writing Texts by Teacher in Palangkaraya ", discusses the transitivity used to analyze Cinderella's narrative texts from 4 high school English teachers in Palangkaraya. The type of processes that dominate in the research are material processes, relational processes and mental processes. Junlin Wang (2010) in his article entitled "A Critical Discourse Analysis of Barack Obama's Speeches", examines Barack Obama's presidential speech using the Functional Systemic Linguistic approach, but only in terms of transitivity and modalities.

There are moreover other researchers conducting such a transitivity analysis two of them are Afrianto and Inayati (2016), who applied transitivity analysis to existential process in a novel (Harry Potter and the Chamber of Secret) and Sujatna (2013) who employed regional and national airline slogan to find the mood and the types of processes. Based on the results of previous research, it can be concluded that research analyzing transitivity, themes, mood structures, complex clauses, nominal groups and lexis has never been done in the form of reading texts in English textbooks in the first grade of Junior High School.

\section{RESEARCH METHOD}

This research is qualitative, using triangulation method to analyze validity of the data. To analyze the data this research uses domain analysis, taxonomy analysis, componential analysis and theme-culture analysis. The analysis is focused on the three aspects of Systemic Functional Linguistics; ideational meaning (transitivity), interpersonal meaning (mood structure), and textual meaning (theme-rheme). In addition, clause complex, nominal group and lexis are used to find out readability.

\section{FINDINGS AND DISCUSSION}

In ideational component, language has the functions of representation. Language is used to send messages, or represent the human experience about the world (reality). Language is used to bring a sense of reality in the world. Ideational function is related to how language expresses human experience (place, objects and activities that create human psychological and physical environment). The first that has been analyzed in this research is transitivity. At the level of lexico-grammatical ideational meaning is manifested in the language through transitivity. Transitivity deals with selection of the process and the role of participants who embodied in reality experience (Eggins, 2004: 205). Transitivity can show how a creature described the experience of life based on the fact that happened around them and themselves. Based on the aspects of experience those realities consist of doing, happening, feeling and being (Halliday, 1985: 101). Table 1 shows the differences result of transitivity between two different reading texts from two different publishers that used by Junior High School students.

\begin{tabular}{|c|c|c|}
\hline Transitivity & Erlangga & Yudhistira \\
\hline Material & 4 & 14 \\
\hline Mental & - & - \\
\hline Verbal & - & - \\
\hline Behavioral & 3 & - \\
\hline Relational & - & - \\
\hline Existential & - & - \\
\hline
\end{tabular}

The transitivity analysis shows that Erlangga's book is more clearly describing the object of discussion in reading text. This is evidence of analysis data that Erlangga's book is used two processes (material and behavioral) than Yudhistira Ghalia's book which is only used one process (material). Material process is process of doing an act. Then, behavioral process has two types of process, verbal behavioral process and mental 
behavioral process. Verbal behavioral process is only containing verbal process, without any further acts. Mental behavioral process is combination both mental process and material process.

The second is structure mood analysis. Structure mood is a form of interpersonal meaning. Interpersonal function is to form social relationship and represents the potential meaning of speaker as participant in the process of interaction or as a speaker and hearer or between writers with the readers. Halliday (1985, 68-69) illustrate when two people use language to interact, one thing that they do is take a relationship between them. Furthermore, in table 2, the analysis shows the differences of structure mood between two different reading texts from two different publishers that used by Junior High School students.

Table 2: Structure Mood Analysis of Erlangga and Yudhistira Ghalia's Book

\begin{tabular}{ccc}
\hline Structure Mood & Erlangga & Yudhistira Ghalia \\
\hline Preposition & 8 & 14 \\
Proposal & - & - \\
\hline
\end{tabular}

It shows that Erlangga's book is used 8 prepositional meaning and Yudhistira Ghalia's book is used 14 prepositional meaning. Prepositional meaning is used to explain a text that described an object.

The third is theme-rheme analysis. Theme-rheme is representing textual meaning. The function of textual language is an interpretation of language in its function as a message, namely the function in forming the text in language. The message is delivered as systematic. This indicates that language has rules in order to convey a good arrangement and organization in constructing text. Table 3 shows the differences of theme-rheme between two different reading texts from two different publishers that used by Junior High School students.

Table 3: Theme-Rheme Analysis of Erlangga and Yudhistira Ghalia's Book

\begin{tabular}{lcc}
\hline Theme-Rheme & Erlangga & Yudhistira Ghalia \\
\hline Textual & 6 & 12 \\
Topical & 2 & 2 \\
Interpersonal & - & \\
\hline
\end{tabular}

Table 3 shows that Erlangga's book is used 6 Textual Themes and 2 Topical Themes. Then, Yudhistira Ghalis's book is used 12 Textual Themes and 2 Topical Themes. The result of the analysis indicates that the clause development pattern of the two texts is good enough. Both of texts use Textual Theme and Topical Theme. Textual Theme is used to connect previous sentence. Topical Theme is a theme that develops a topic in discourse.

The last are clause complex, nominal group and lexis. Clause can be defined as the biggest grammatical unit, and clause complex are two or more clauses which connected in logical (Gerot and Wignell, 1995:82). Clause can be divided into major clause and minor clause. Major clause can be divided into two clauses, clause simplex and clause complex. Clause simplex is one process and clause complex are two processes. Which is called by nominal group is the expansion meaning of the word meaning itself. Nominal group is 'word complex', consist of main meaning (pre-modifier) and element of explanation (post-modifier) (Halliday, 1994). Lexis is the realization of ideational meaning, interpersonal meaning, textual meaning or the level of word. Word in textual meaning described the process of physical reality or social into the world language that is discussed in the realization of congruent and incongruent. Then, descriptive lexis describes experiential reality in the absence of opinion or opinion of describing. In the science world, descriptive lexis is used to keep objectivity in writing or talks. In addition, attitudinal lexis describes experiential meaning but implied the opinions, taste, and attitude toward the reality. Lexis attitudinal indicates the meaning of word. Those three aspects are used to find out the readability of those two textbooks. Table 4, 5 and 6 shows the differences result of clause complex, nominal group and lexis between two different reading texts from two different publishers that used by Junior High School students.

Table 4: Clause Complex Analysis of Erlangga and Yudhistira Ghalia's Book

\begin{tabular}{ccc}
\hline Clause Complex & Erlangga & Yudhistira Ghalia \\
\hline Complex & 11 & 8 \\
Simplex & 1 & 6 \\
\hline
\end{tabular}

Table 5: Nominal Group Analysis of Erlangga and Yudhistira Ghalia's Book

\begin{tabular}{ccc}
\hline Nominal Group & Erlangga & Yudhistira Ghalia \\
\hline Pre-Modifier & 13 & 14 \\
Post-Modifier & - & - \\
\hline
\end{tabular}


Table 6: Lexis Analysis of Erlangga and Yudhistira Ghalia’s Book

\begin{tabular}{ccc}
\hline Lexis & Erlangga & Yudhistira Ghalia \\
\hline Incongruent & - & 8 \\
Congruent & - & - \\
Descriptive & 21 & 29 \\
Attitudinal & 4 & 10 \\
\hline
\end{tabular}

The table (the clause complex, nominal group, and lexis analysis) shows that Yudhistira Ghalia's book tends to use three components in reading text than Erlangga's book. When the three components are increasingly and often used in text, they are signifying the use of many difficult words in the text. It implies that the text is more difficult to understand for students of Junior High School. This proves that reading text in Yudhistira Ghalia's book is more difficult and complicated for students in Junior High School than Erlangga's book.

The theme-culture analysis shows that Erlangga's Book is more "highly regarded" in Indonesia than Yudhistira Ghalia's Book. It was proven from the number of books which has been sold out. Erlangga's Book has been published around 1800 title of books from the level of pre-school, elementary school, junior high school, senior high school until university and also publics. The data obtained in official website of Erlangga Publisher, www.erlangga.com. Meanwhile, Yudhistira Book's has been published around 382 title of the book from the level of elementary school, junior high school and senior high school. The data is obtained in official website of Yudhistira Ghalia Publisher, www.yudhistira-gi.com. Reviewed in terms of its language, and its relation to economic purposes, the use of the easier language in Erlangga's Book is related to the published number of the books that higher than Yudhistira Ghalia's Book. The minimum use of clause complex, nominal group and lexis in the book is more suitable for the Junior High School students.

In addition, for transitivity analysis Erlangga's Book used two processes (material and behavioral) and Yudhistira Ghalia used one process (material). The issue here is that the behavioral process can help to describe the objects more clearly in reading text. It can be presuming, from the above analysis that Erlangga's Book is more accepted by publics and is more helpful in maintaining the purposes of Curriculum 2013 - in term of character building.

\section{CONCLUSION}

The analysis of ideational meaning in Erlangga's book and Yudhistira's book can be determined by transitivity analysis. Element of transitivity that makes the difference of those two text books is its process. In Erlangga's book there are two processes (material and behavioral). Meanwhile, in Yudhistira Ghalia's book there is only one process (material). Then, analysis of interpersonal meaning in reading text from two books publishers can be seen from mood structure. It shows that both of text used preposition meaning. In textual meaning, it analyzes from theme-rheme analysis. Theme-rheme analysis shows that both of texts used theme topical and theme textual. These results of analysis data lead to the assumption that content of reading text in Erlangga's book is more detail in describing an object than Yudhistira Ghalia's book.

Likewise, the research also shows that reading text in Yudhistira Ghalia's book is dominated by the uses of clause complex, nominal group and lexis. It can be concluded that reading text in Yudhistira Ghalia's book is more difficult and complicated for students of Junior High School than Erlangga's book.

Additionally, it is also recommended for the next researchers who are concerned with such a kind of study and are more experts in generalizing and updating this research, to do further research related to this topic (in different publisher's books and different texts) through Systemic Functional Linguistics approach. However, whatever the samples and the instruments will be used, hopefully they can give more implication to the development of linguistic study and education processes.

\section{REFERENCES}

Afrianto, \& Inayati, A. (2016). Existential Process in Harry Potter and the Chamber of the Secret: A Systemic Functional Linguistic Study. Teknosastik Journal, 14 (1).

Eggins, S. (2004). An Introduction to Systemic Functional Linguistics. London: Continuum.

Gerot, L. \& Wignell, P. (1995). Making Sense of Functional Grammar: An Introductory Workbook. Cammeray, NSW: Antipodean Educational Enterprises.

Halliday, M. A. K. (1994). An Introduction to Functional Grammar. London: Arnold.

Halliday, M. A. K. (1985). Context and Text: Aspect of Language in Social Semiotic Perfectives. Geelong: Deakin University Press.

Luardini, M. A., \& Asi, N. (2014). An Analysis of Linguistics Competence in Writing Texts by Teacher in Palangkaraya. International Journal of English and Education, 3(2).

Muqoffi, S. (2013). Analisis Buku Teks Ta'lim Al-Lughah Al- 'Arabiyyah Pendidikan Bahasa Arab SMP/MTs Muhammadiyah kelas VII. Yogyakarta: UIN Sunan Kalijaga. 
Naz, S., Alvi, S. D., \& Baseer, A. (2012). Political Language of Benazir Bhutto: A Transitivity Analysis of Her Speech 'Democration in Pakistan'. Interdisciplinary Journal of Contemporary Research in Businees, 4(8).

Nurdaeni, R. (2013). Analisis Buku Teks Pelajaran Bahasa Inggris Sekolah Dasar Berdasarkan Standar Penulisan Buku Teks Pelajaran. Bandung: UPI.

Sujatna, E. T. S. (2013). Mood System and Transitivity of Airlines Slogan - A Comparison of National and Regional Airlines. IJEL, 3(3).

Teich, M. (1992). Fundamentals Photonic. New York: John Wiley and sons.

Utami, A. R., Aminatun, D., \& Fatriana, N. (2020). Student Workbook Use: Does It Still Matter to the Effectiveness of Students' Learning?. Journal of English Language Teaching and Learning, 1(1), 7-12.

Wang, J. (2010). A Critical Discourse Analysis of Barack Obama's Speeches. Journal of Language Teaching and Research, 1(3).

Qodriani, L. U., \& Kardiansyah, M. Y. (2018). Exploring Culture in Indonesia English Textbook For Secondary Education. Jurnal Pendidikan Indonesia (JPI), 7(1): 51-58.

\section{BIOGRAPHY OF AUTHOR}

Tyas Desita Wengrum studied in the Linguistic study program, Sebelas Maret University. She received her Master's Degree in 2015. She is an English Lecturer in Mitra Indonesia University (Bandar Lampung). 